Универзитет у Новом Саду, Педагошки фракултет Катедра за језик и књижевност, Сомбор

DOI 10.5937/kultura1549176P УДК 821.163.41.09-31

оригиналан научни рад


ПРИКАЗЗВABHA ХЕННИКЕПИРАНОСТИ

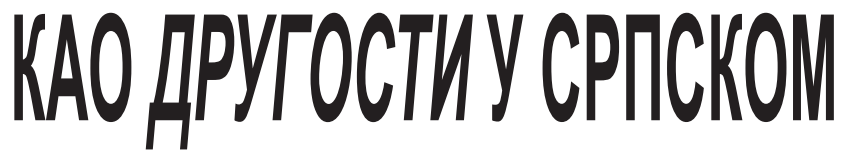
POMAHY HA TOYETKY XXIBEKA

\begin{abstract}
Сажетак: У овом раду посматране су наративне стратегије и начини моделовања јунака с извесним поремећајима као другог у српском роману на почетку XXI века у контексту постпостмодернистичке поетике и постструктуралистичке (фукоовскодеконструктивистичке) интерпретативне парадигме. Иако на први поглед изгледа да ово интересовање делује као потврда кризе нарачије, која се исирпьује у интересовању за бизарно, то ипак није тако. Резултати показују да се различитост те врсте у посматраним романима приказује не као стигматизаиија, већ као борба за право на особни идентитет, који се не уклапа у стандарде нормативног идентитета.
\end{abstract}

Кључне речи: постпостмодернизам, роман, болест, идентитет, другост, друштвена улога

Промена поетичке парадигме на почетку новог миленијума, неминовно, померила је, најпре стваралачке, а потом и 
интерпретативне оквире од бинарне релације тзв. стварносна проза - постмодерна проза, доминантне на српској прозној сцени у другој половини последње деценије XX века. Не само да је романескни нелинеарни израз павићевског типа прихваћен и формирао одређене токове, него је и његов лексикографски поступак, дословном применом, постао носећа структура за неке нове наративе („азбучни романи” Мира Вуксановића Семољ гора, Семољ земља и Семољ sудu). Иако је Павићев постмодерни проседе (од објављивања романа Хазарски речник) ${ }^{1}$ обележио значајан отклон од традиционалног фабулирања (полифони и мозаички романи, остварени променом рефлектора, наизменичним смењивањем различитих временских перспектива, модуса приповедања, приповедача, ликова и сл), оно, уистину, никада није у потпуности напуштено. Штавише - могло би се рећи да је само значајно унапређено, при чему је лабилност жанровских оквира традиционалних форми романа, тј. појава протејских, хибридних романескних форми, удружена с неким новим платформама комуникације (Д. Вулета Ђавољи nотпис, С. Владушић Forward), томе додатно допринела. Када је о литерарном поступку реч, постмодерни наратив, с обиљем интертекстовних (в. нпр. М. Новаковић Страх и юегов слуга, 2000), метатекстовних (metafiction) и аутореференцијалних места сменили су „профани” авант-поповски поступак ${ }^{2}$ - српска проза парсонсовско-хорнбијевског типа, писана из женске родне перспективе (Бобић Мојсиловић), увођење алтернативне стварности (М. Новаковић Johan's $501,2005)$, ескапизам и трагање за сопственим идентитетом у супкултурном или просторима технолошки и цивилизацијски супериорнијим завичају (Албахари, Тасић), лирски обојена бајколика историјска фикција (Г. Петровић), уз јачање

1 Превратнички значај појаве овог романа, у поетичком смислу, већ је уочен: „Датумом признања победе постмодернистичке поетике може се условно сматрати 1984, када је Данило Киш добио Андрићеву награду за Енциклопедију мртвих (1983), а Милорад Павић Нинову награду за најбољи роман у 1984."; Татаренко, А. (2013) Поетика форме у прози српског постмодернизма, Београд: Службени гласник, стр. 25.

2 „Посезању постмодерниста, као представника елитног дискурса, за дискурсом масовне културе, у прози XXI века одговара огледални процес у тривијалној (жанровској) литератури, који прибегава позајмљивању литерарних средстава из фондова 'високе књижевности'. Традиционалне 'жанровске' сижејне схеме и јунаци спајају се са спољашњим цртама 'озбиљности' и 'литерарности' преузетим од постмодернистичког модела. Као пример навешћемо мегахитове Љиљане Хабјановић Ђуровић (нпр. романсирано 'житије' Свете Петке, Петкана, 2002), Мирјане Бобић Мојсиловић (љубавни роман Срце моје, 2007, стилизован у литературоцентричном маниру), Марије Јовановић (љубавни роман с умецима филозофског дискурса Сплеткарење са сопственом душом, 2001)"; Исто, стр. 266. 
фантастике (3. Живковић, Б. Кнежевић, У. Петровић), као и најразличитија експериментисања са формом.

Уосталом, разноликост у погледу форме, per se, не може бити пресудно обележје савремених поетичких токова, како сматрају неки савремени истраживачи, будући да је, роман, као врста, „протејска форма која се из дјела у дјело мијења и која своје разноврсне садржаје излаже у исто тако разноврсним облицима" коришћење различитих експеримената у погледу форме (од [неуспелих] травестирања неких традиционалних књижевних врста, ${ }^{4}$ преко ауторских жанрова до хипертекстуалних и трансжанровских експеримената), била би пре иманентна особина романа као врсте, која, у српском постмодерном (и постпостмодерном) роману, постаје све запаженија, него његова differentia specifica. У поетичко-жанровском смислу, „за постмодернисте с почетка XXI века карактеристични су за ову парадигму традиционални фрагментарни 'ентропијски' романи, (Басара), трансжанровски експерименти (Павић), стварање метатекста на интержанровској основи (Дамјанов), игра са жанровима која сад предвиђа повратак ка традиционалној жанровској номенклатури и њено коришћење као средства дуплог кодирања (Павић, Продановић), “5 односно различити видови деконструкције традиционалних наративних стратегија. Међутим, оно што се чини значајнијим у контексту овог истраживања јесте тематска раван дела, тачније - ширење тематског регистра, често повезано с трагањем за идентитетом, у контексту нове (лакановско-деридијанско-фукоовске) филозофске матрице.

Уколико се прихвати теза да је свака јединка „културно интерпелирана" (Алтисер), односно друштвено препозната с обзиром на позицију коју заузима у заједници и одређена датом јој улогом, онда је слобода избора и одлучивања илузија, јер су поступци појединаца, самим тим, унапред дефинисани центрима моћи и дискурзивним праксама које они пласирају. ${ }^{6}$ Откривање сопственог идентитета, у том случају, није ништа друго до - фантазма, „погрешно

3 Лешић, 3. (2010) Теорија књижевности - 2. изд., Београд: Службени гласник, стр. 397-398.

4 Упоредити нпр. псеудохронике Милоша Петковића (трилогија Перунов хроничар), реализоване, добрим делом, у жанровском хоризонту очекивања епске фантастике, с извесним утемељењем у националној историји.

5 Татаренко, А. нав. дело, стр. 35.

6 Kaler, B. Dž. (2009) Teorija književnosti: sasvim kratak uvod, Beograd: Službeni glasnik, str. 136-137. 
препознавање себе у одразу"7, у лакановском смислу речи, односно у слици коју други стварају о нама, у различитим социјалним интерпретацијама. Стога, писање о Различитости $^{8}$ у српским наративима на почетку новог миленијума могло би се схватити као још једна потрага за идентитетом, овај пут - насупрот доминантних наративних стратегија и интерпретативних, односно херменеутичких пракси. Да ли су особе, стигматизоване болешћу/физичком обележеношћу/деформитетом, довољно литерарно убедљиве да буду носиоци те различитости, чак и када су приказане у неким типичним животним ситуацијама, као што је потрага за љубављу и прихватањем, или је реч о настојању да се неизрабљеном (девијантном?) тематиком освоји оно мало слободног простора, колико је остало српским писцима који за оригиналношћу трагају у сфери тематике?! Будући да су сви друштвени (а ваљда и литерарни) табуи до сада већ прекршени, таква тематско-карактеролошка оријентација могла би изгледати само као израз немоћи у трагању за новим, а, посредно, осведочити о кризи нарације, која се срозава до једне reality show емисије из програмске схеме TLC-a. ${ }^{9}$ Да ли је то одиста тако, тј. да ли савремена проза, и поред кокетовања с темама које су на граници прихватљивог и етички допуштеног, може да досегне ту фантазмагоричну оригиналност, а да притом не западне у тривијалност овог ТВ формата биће показано на примерима романа Пољубац Гордане Ћирјанић (2007), Ми различити Веселина Марковића (2011) и Крваво зелено Ивана Бачића (2015).

\section{Пољубаи Гордане Ћирјанић $\hbar^{10}$ или буђење телесног}

Овај роман Гордане Ћирјанић прати живот шездесетогодишњег Луке, инвалида, чије је тело, од десете године, деформисано неким обликом дечје парализе тако да је остао непокретан, везан за инвалидска колица. Самим тим, и његов духовни и физички развој био је половичан - церебралан, остварен симболичком линијом духовне вертикале, односно

7 Исто, стр. 134.

8 Један од романа који ће овом приликом бити узет у разматрање (уједно, и најбољи од посматраних), Ми различити Веселина Марковића, управо ту различитост ставља у први план, већ у насловној синтагми.

9 Реч је о емисији The Undateables (емитује се од 2012), која приказује особе са различитим физичким или психичким недостацима. Назив ове документарне серије тешко је преводив, а у некаквом незграпном буквалном преводу, могао би се схватити као - они са којима је тешко изаћи на састанак, партнери с хендикепом и сл.

10 Сви даљи наводи у тексту биће дати према: Ћирјанић, Г. (2007) Пољубаи - 3. изд., Београд: Народна књига - Алфа. 
(само) горњом половином тела, те он описује себе у једној ауторефлексији као неког ко је „много више живео главом него телом" "11. Још за време своје младости обележен као инвалид, у тренутку када, делом непромишљено, делом намерно, његов тадашњи друг девојци која му се допадала (и којој се, по свему судећи, и он сам допао) открива Лукин хендикеп, он прихвата дату му друштвену улогу као сопствени пораз и саживљава се са њом, одричући се права на личну срећу и живећи, горд и унесрећен, „са дечјом чедношћу у телу зрелог мушкарца, с осетљивошћу живе ране у човеку несвакидашње храбром и разборитом". ${ }^{12}$

Лукин привидно ушушкани живот дестабилизује се управо приликом контакта са женама - неочекиваном ерекцијом док се сестра Клара старала о њему као петнаестогодишњем богаљу у болници; несретним крајем младалачке љубави с Дором, наглим раздвајањем с Дрином; стриптизом комшинице Данијеле; само за његове очи; провокативним уринирањем, њему наочиглед, рођаке Наталије... Однос с братовљевом супругом, Булком, приказан је као комплексан, динамички, па чак и - контрадикторан. Крупна, једра и снажна (и у психичком, и у физичком смислу речи) Булка је жена коју је Лука, како сам исповеда, најбоље упознао и „најдуже и најискреније волео." 13 Испрва њен савезник, особа од поверења и раме за плакање, Лука, с временом, постаје њен терет. Блискост у односу, постепено, Лука изједначава с физичком блискошћу са њом као са женом. Навалу еротског он, ипак, савладава, затомљујући дубоко у себи недозвољену жељу за снахом. Булка, опет, њихов однос поједностављује и своди на меру површног и друштвено прихватљивог - на дужност

11 Исто, стр. 8. Прихватајући ставове других о себи, овај Ћирјанићкин лик интелектуалну надоградњу види као једини легитимни и могући пут развоја: „Телесно закинут и ограничен, требало је да развијам оно што ми је остало нетакнуто - дух. Требало је да поставим себи више циљеве да се образујем. Да сам у великом свету синуо духом, да сам развијао свој интелект уместо што сам се задовољавао тиме да се у скученој средини издвајам здравим разумом, све би било другачије.”; Исто, стр. 56. Па ипак, даљи ток његових мисли показаће да је интелектуални развој неопходан само да би био стављен у функцију досезања личне среће - у љубави: „Можда бих тада имао некакве изгледе код здравих жена, лишених предрасуда. Само бих међу паметним и осетљивим женама могао да очекујем, овакав какав сам, чудо љубави - да ме нека од њих заволи због мог карактера и умних постигнућа, а да јој не буде пресудно моје тело."; Исто. Само тако, сматра он, могуће је досегнути своју целовитост бића, упркос физичком хендикепу (отуда и позивање на Хокингов пример, на истој страни одакле су и цитирана места - можда и као фингирање несвесне пројекције себе у овом славном научнику).

12 Исто, стр. 125.

13 Исто, стр. 73. 
и обавезу. ${ }^{14}$ Потиснута жеља и њено осујећење, код Луке, довешће до дистанцирања од Булке, а губитак поштовања с њене стране изазваће његову заједљивост и отворени бунт. ${ }^{15}$ Преломни моменат њиховог односа, или, у њеној интерпретацији, тренутак када је Луку „протресао закаснели пубертет”, представља његов пољубац с Катарином.

Тај пољубац ${ }^{16}$ током нестанка струје, на новогодишњем дочеку 1. 1. 1996, током „петнаестак минута јутарњег сумрачја"17 је, уједно, и централно место романа, најеротичнија сцена, али и тренутак када пред читаоцем васкрсава стари (средњовековни) спор између духовног и телесног - conflictus corporis et animae. Неочекиван а ипак тражен, доживљен по „први пут у животу, с педесет година"18, овај пољубац доводи до буђења бића, изазива у њему „чудесно осећање"19 прихватања и блискости и открива му „смисао живота" ${ }^{20}$. И док глас који припада Катарининој наративној перспективи открива да је то била ствар тренутка, а да његов „доживљај нема много заједничког с догађајем који га је подстакао"21, за Луку је то био тренутак откровења, догађај који га је просветлио, lucida intervalla коју је вредело чекати претходних педесет година. Њој је тај пољубац означио тренутак блискости с другим, тј. с њим као особом, без бремена сажаљења или других емоција те врсте према њему као инвалиду: „Мени се наметнула твоја прича, као метафора усамљености - дубоко верујем да еротику не исцрпљује ни полност ни друго биће. Али треба досегнути другог да би се спознала запремина самоће". ${ }^{22}$ И сама усамљеник, као и он што је, она, на тренутак, уочава сличност и прихвата га, лишавајући га притом, котрљања „по свету у форми чистог бића"23. Он, доживевши на тренутак целовитост бића, употпуњен њеним телом, више није инвалид, већ остварена јединка. Доживевши, на тај начин, максимум себе, Лука више

14 „Ако сам је икада и занимао као непоновљиво људско биће, занимао сам је површно: као разуман човек и као инвалид са својим потребама"; Исто, стр. 75.

15 Булки изгледа као да је Лука искористио њено поверавање - да би касније могао да је повреди, у тренуцима раздражљивости и болесне осетљивости; Исто, стр. 92.

16 Исто, стр. 120-121.

17 Исто, стр. 119.

18 Исто, стр. 104-105.

19 Исто, стр. 104.

20 Исто, стр. 129.

21 Исто, стр. 149.

22 Исто, стр. 124.

23 Исто. 
не пристаје ни на шта мање од тога. Када се сликарка Катарина враћа сигурности брачног живота, у (поновни) брак с бившим мужем, затварајући неке теме и врата свог интимног света за собом, заувек, Лука нестаје. И док се нарација у роману плете у трагање за несталим Луком, Булка, на свој ужас, открива на крају романа да је Лука, кога је књижарка једном видела, „онако самог у својим инвалидским колицима, на усамљеном месту и загледаног у море” као „слику и прилику људске немоћи"24 извршио самоубиство, не пристајући ни на шта мање од пуноће живота, одбијајући да живи само као духовно биће, спајајући се, на крају, физички, с плавом пучином - недостижним даљинама и просторима чежње.

\section{Ми различити Веселина Марковића ${ }^{25}$ Ars combinatoriae}

Суптилност наративних стратегија Веселина Марковића огледа се не толико у облику приповедања и оригиналности фабуле, колико у поступку индивидуализације ликова. Причу „воде” два наратора, који су уједно и главни ликови романа - Валентина (Вања) и Владимир. Оба ова лика су, у извесној мери, друштвено неприлагођени: Вањина неприлагођеност огледа се у обележености физичким изгледом, тачније - бојом коже (она има неку врсту генетског поремећаја, односно, недостаје јој ген задужен за разлагање билирубина из организма, услед чега, његовим депоновањем, кожа јој постаје жућкаста, а органи постепено одумиру и животни век се скраћује); Владимирова самоизолација психичке је природе - приликом клизања по леду, несрећним случајем, утопила се његова сестра од ујака, Ана, после чега, остатак свог живота он проводи у испитивању каузалитета те исходишне трауме, односно у покушају да се, збрајањем фактора који су утицали на њено утапање, ослободи (имагинарног али снажног) баласта кривице. Слични, неодређени осећај кривице понела је и Вања:

Zajednički imenitelj priča Vladimira i Valentine, ne samo $u$ odnosu na okolinu, nego i međusobno različitih ličnosti, povezuje slično osećanje krivice junaka i njihovo traganje za uzrocima naizgled bezizlaznog stanja u kojem su se, ne svojom zaslugom $i$ voljom, našli. Zahvaljujući tom traganju, $u$ oba slučaja zasnovanom na naučnom, logičkom principu, ali i nizu peripetija, Mi različiti podsećaju na kriminalistički

\section{4 Исто, стр. 53.}

25 Сви даљи наводи из романа биће дати према: Marković, V. (2011) Mi različiti-2. izd. Beograd: Stubovi kulture. 
roman - Valentina, službenik u policijskoj arhivi, u pokušaju da sazna da li njena bolest izaziva poremećaje u rasuđivanju, počinje da istražuje davnašnje ubistvo, dok Vladimir, $u$ potrazi za racionalnim objašnjenjem smrti sestre, otkriva, $u$ maniru detektiva, niz podataka koji će ga osloboditi osećanja krivice. $^{26}$

Ова траума Владимира и професионално детерминише, те он своје истраживање за докторску дисертацију ради у области статистике, тј. теорије вероватноће, везане за случајеве/испитанике које интервјуише у свом кабинету (између осталих, и Вању), а којима се догодило неко „чудо“, тј. наизглед необјашњиви стицај околности. Но, овакво рационализовање исходишног случаја ипак не доноси прижељкивано олакшање:

U beskonačnom svemiru, u kojem iznova i iznova, u beskonačnom broju pokušaja, nastaju novi svetovi, sve što je nekad moguće postaje stvarno. I najmanje verovatan slučaj mora se dogoditi. Mora [...] Tačna je ta ideja, ali za mene će ostati upravo to - samo ideja. Teši me izvesnost što će neka Ana, negde, izbeći smrt u ledenoj vodi, iživeti dugo i srećno, ali uteha je apstraktna kao i taj svet. Ja sam ovde, suočen sa sobom $i$ sopstvenom kombinacijom događaja, a druge kombinacije nikada neću iskusiti. ${ }^{27}$

Оно наступа тек када његово детективско трагање за актерима, сведоцима, узроцима и последицама доведе до сазнања да је, у ствари, „главни кривац” за Анино утапање геотермални извор који је довео до тога да се лед на језеру - управо на месту где је Ана пропала - делимично отопи и постане порозан. Симболичко ослобађање од кривице дешава се у моменту када он то своје откриће подели с породицом, са којом је та тема била запечаћена до даљњег, све до овог момента. Његова животна потрага је тиме окончана, те он напушта не само пријављену дисертацију, већ и посао на факултету. Овим напуштањем пажљиво грађене друштвене улоге (вундеркинд - најбољи студент - асистент и кабинетски фрик) Марковићев Владимир надраста себе самог изборивши се

\footnotetext{
26 Dunđerin, A. Evropski nadrealizam Veselina Markovića, 7. 7. 2011, 15. 10. 2015. http://www.pecat.co.rs/2011/07/evropski-nadrealizam-veselina-markovica/

27 Marković, V. (2011) Mi različiti - 2. izd. Beograd: Stubovi kulture, стр. 170-171.
} 
за право на пуноћу сопства ${ }^{28}$ и ушавши у отворену везу с Вањом (а уједно излазећи из наративног света дела). ${ }^{29}$

За разлику од њега, Валентинина имагинарна кривица долази до изражаја приликом њеног константног повлачења пред светом (осим у дискотеци, чија разнобојна светла чине да сви изгледају исто). Пошто се оваквој мимикрији не може прибећи у свакодневном животу, она вечито одлучује на основу тога хоће ли је мање њих запазити уколико иде пешице, мање прометним уличицама (што дуже траје), или аутобусом, окренута леђима (што је, уистину, краће, али је изложенија погледима радозналаца). Како би приказао Вањин доживљај себе саме, Марковић користи механизам трансфера. Једном приликом, наишавши на чланак о албино људима у Африци, који су своју различитост плаћали животом (белопутост албино детета сматрана је знаком поседовања магијске снаге и моћи, те су, ритуалним убиством, канибализмом и сл. његови саплеменици настојали да дођу до те магијске снаге и благостања, тј. да унесу у себе део нуминозног $)^{30}$ она почиње да размишља о себи:

Živim u kulturnoj sredini, pa će ovde samo zuriti u mene, došaptavati se i sklanjati decu. Umesto zujanja strela, slušaću glupe komentare $i$ vešte izgovore zašto sam izgubila posao. Nije mala razlika. Malograđanština je bolja od divljaštva, zar $n e ?^{31}$

28 Овакав завршетак романа поједини критичари сагледавају као карактеролошку (и мотивацијску) недоследност, која одудара од консеквентности (свеукупног) Марковићевог грађења ликова и каузалности наративног следа: Marković je barem do epiloga, dosledno poštujući logiku psihološko-socijalne motivacije, uspešno gradio glavne likove. Suptilno nijansirajući njihove sličnosti i razlike, autor je jasno stilsko-jezički razdvojio njihova pripovedanja (uzimajući u obzir njihove različite polove, različita obrazovanja, profesije, životne situacije) u kojima infantilnu perspektivu, kako junaci-naratori sazrevaju, zamenjuje ugao gledanja odraslog čoveka. Osim toga, Marković se dobro snašao u korišćenju različitih žanrovskih obrazaca, ne dozvoljavajući nijednom da prevlada i ugrozi originalnost narativne strukture. Дунђерин, А. нав. дело (http://www.pecat.co.rs/2011/07/ evropski-nadrealizam-veselina-markovica/).

29 „Kao da sam nekoga izneverio, već pukom činjenicom da osećam radost, da sedim i ćaskam, iako nazirem puteve koji se spajaju baš u ovoj tački.”, каже Марковићев Владимир. Није ли тај неко - управо сам Читалац, односно она његова тежња коју Еко [Есо] назива intentio lectoris - в. Eko, U (2001) Granice tumačenja, Beograd: Paideia, 2001. Притом, не само да се деконструише лик (барем онај који је читалац могао пратити све до самог краја романа), већ и једна интерпретативна пракса, сходно којој овакав завршетак романа делује сентиментално-мелодрамски.

30 Marković, V. нав. дело, стр. 158.

31 Исто. 
Чак ни разумевање малограђанске средине није много подношљивије од тог:

Sećam se dve devojčice iz moje škole, koje su bile pune razumevanja za sve što kažem, pa makar to bilo suprotno od onoga što sam govorila prethodnog dana, kada su takođe bile pune razumevanja. Tolika uslužnost bi mi se smučila, jer me u istoj meri kao i nipodaštavanje podseća na moj nedostatak, pa bih tražila društvo onih koji su me odbacivali. S njima sam bar znala kako da se nosim. ${ }^{32}$

Њено неуклапање у нормативне идентитете какве исписује дискурс културе коме она припада, понајбоље се види у потреби да буде окружена особама које је не прихватају, будући да су, у таквој подели улога, њене позиције јасне, као и стратегија / тип односа. Ситуирање овог лика у просторно-временске оквире који би одговарали, рецимо, некој скандинавској земљи (намерна неодређеност у одсуству именовања назива града као да доприноси појачању фикционалности тог света) осамдесетих година прошлог века је послужило за „temeljnu refleksiju o statusu svih 'drugih', a naročito onih koji koji doživljavaju represiju u društvenom i kulturnom prostoru s obzirom na njihovo nepristajanje na nametnute obrasce - arbitrarno utvrđene" 33 улоге. И док се Владимиров старији брат опредељује за антирелигиозну, самониклу идеологију, односно својеврсно богоборство и повлачење из света, Владимир и Валентина прихватају своју различитост, али и једно друго. Притом, прихватајући сопствени парадоксални положај, они прихватају и свет у коме су јер „nета dakle, kulture bez ideologije, što takođe znači da je subjekat (a ne pojedinac) sputan iluzornom svešću sopstvene slobode ('ono sam što želim da budem'), a istovremeno je samo zarobljenik simboličke kulture u kojoj učestvuje" ${ }^{34}$ Слобода се, стога, конституише као привид, а тек прихватање те илузије са собом доноси живот између задатости и испитивања богатог низа комбинаторичких могућности, датих у Епилогу:

Ništa nije rekao.

Dvadeset šest godina je iza mene. Koliko li ih je ispred? Sigurno ne toliko. Kada još dvadeset šest godina prođe, ja ću biti mrtva, a on ko zna gde. Ušla sam u predgrađe smrti, $i$ ponekad se jako bojim. Tada kažem sebi - čitave godine su još uvek nedodirnute. Jednog dana će mi otkazati neki od

\section{2 Исто.}

33 Bužinjska, A. i Markovski, M. P. (2009) Književne teorije XX veka, Beograd: Službeni glasnik, стр. 502.

34 Bužinjska, А. i Markovski, М. Р. нав. дело, стр. 586. 
unutrašnjih organa, ali taj dan je daleko. Sutra popodne moraću da se vratim u grad, jer će preksutra biti vreme da ležim u plavoj svetlosti, ali i ti dani su daleko. Sedećemo u restoranu, razgovaraćemo, sumrak će padati, ljudi će dolaziti i odlaziti, na recepciji ću dobiti ključ, potom ću se popeti u sobu, istuširati se, oprati zube i uraditi još desetinu takvih običnih stvari, naizgled nebitnih, ali zapravo dragocenih, jer u sebi sadrže vreme.

Onda će doći vreme za spavanje. Možda će on otići već večeras. Možda će ostati u hotelu, ali ćemo samo ležati, svako u svojoj sobi, a sutra otići, svako na svoju stranu. A možda ćemo voditi ljubav. ${ }^{35}$

Дијапазон могућности избора остаје отворен - у складу с постмодернистичким нелинеарним / хипертекстовним завршецима романа. ${ }^{36}$ Стога, погрешна су сва она тумачења која предност дају једном тумачењу краја дела (нпр. мелодрамско-сентименталистичком) науштрб неког другог:

Priče Vladimira $i$ Valentine uliće se u nekoliko navrata u isti narativni rukavac, poslednji put u epilogu romana, kada iznenada u idiličnoj atmosferi dolazi do još jednog neočekivanog obrta - emotivnog zbližavanja junaka koje će možda, kako naslućuje Valentina, završiti vođenjem ljubavi. Ovakav završetak romana, u kojem se mogu uočiti i konture ljubavne melodrame, donekle može da označi izlazak junaka iz začaranog kruga slučajnosti i nužnosti, te da predstavi naznaku zametka njihove slobodne volje, koju do tada, dok nisu razmenili iskustva o različitosti, prinuđeni da žive sa posledicama malo verovatnih događaja, nisu ispoljavali. Međutim, sam čin seksualnog opštenja za junake koji su poput njihovog tvorca dosledni ateisti, može da predstavlja samo kratkotrajni trenutak sreće posle kojeg će ponovo, užasnuti, okrenuti glavu ka praznini. U tom smislu, iznenadni optimistički obrt, usled kojeg egzistencijalistički bunt i krik odjednom ustupa mesto sentimentalističkoj patetici, nije baš najsrećnije rešenje (Deus eks mašina), mada je u skladu sa principom verovatnoće (jedan $u$ milion). ${ }^{37}$

Саодносно томе, „у оба случаја интерпретација [...] одступа од себе саме, јер да би се наметнула мора развијати интерпретацију која јој се супротставља" 38 , односно саму

35 Marković, V. нав. дело, стр. 360-361, истакао Д. П.

36 Упоредити: Татаренко, А. нав. дело, стр. 301.

37 Дунђерин, А. нав. дело.

38 Луси, Н. Реторичко читање, у: Књижевна реторика, приредио Радовић, М. (2008), Београд: Службени гласник, стр. 173. 
себе деконструише, што у читању није случај. Ако не постоји број „коначних завршетака”, тим пре не би смео постојати ни само један (привилеговани) интерпретативни став о њима, који је, нужно, конструисан. Уместо тога, ова нејасноћа у погледу краја дела, тј. сусрет с два или више једнако вредна тумачења једино би се дала разрешити превазилажењем „или-или” релације (између ова два лика, субјекта и објекта, читаоца и текста, света дела и света реалности). Нејасноћа коју генерише Владимирово ћутање (Ništa nije rekao) допушта реализацију било којег од Валентининих „можда”, што омогућава де мановско „узајамно поништавање" (привидних) бинарних опозиција, односно ширење значењских могућности откривањем „супротстављених снага које формирају значење текста" ${ }^{\prime 3}$.

\section{Крваво зелено Ивана Бачића ${ }^{40}$ или другачији поглед на све(т)}

Овај првенац младог аутора, пажљиво компонован и опрезно наративно вођен, далеко је од тога да би се могао сматрати почетничким романом. Одабравши наративну стратегију аукторијалног приповедања ${ }^{41}$ у коме је персонални приповедач (који претендује, псеудодокументарним поступком, да истисне аутора, али у томе, наравно, не успева) естетскилитерарно мотивисан (он је бивши полицајац, инспектор, записничар истражног судије - где је и налетео на „досије једног неуобичајеног случаја") ${ }^{42}$, он заузима такву позицију која је негде на међи света дела и реалности, чиме се дестабилизује граница између текста и стварности и уводи својеврсна означитељска напетост - није ли приказани туробни свет управо - стварност у којој ми живимо?!

Писан у неореалистичком маниру, роман Ивана Бачића ипак се поставља као супериоран у односу на друге романе тог проседеа (рецимо, Канце М. Видојковића). Чак, извесна језичка незграпност ${ }^{43}$ која се да̂ уочити током читавог романа као да је литерарно мотивисана и условљена ликом главног приповедача:

\footnotetext{
39 Kaler, Dž. нав. дело, стр. 144.
}

40 Сви даљи наводи у тексту биће дати према: Bačić, I. (2015) Krvavo zeleno, Beograd: Nova poetika - Argus books \& Magazines.

41 Терминологија која се односи на форме приповедања и наративне ситуације преузета је од немачког наратолога Франца Штанцла [Stanzel] - видети: Штанцл, Ф. (1987) Типичне форме романа, Нови Сад: Књижевна заједница Новог Сада.

42 Вас̌ić, І. нав. дело, стр. 9.

43 Роман у извесној мери оптерећује мноштво лекторских пропуста, који, опет, указују на одсуство професионализма у раду идавача овог романа. 
Roman jeste ispisan gotovo zapisničarski, hladno, namerno šturo, bez preteranih ulaženja u dubine osećanja, jer ga pi$\check{s}$ e, kako je i naznačeno u nastavku one prve rečenice, bivši policajac, zapisničar sa suđenja, objektivni posmatrač, rekla bih stravičnih događaja i isprepletanih sudbina koje samo život može da ukrsti, a pisac mudro da iskombinuje i poveže u celinu. $^{44}$

Стога, такво литерарно транспоновање животних реалија постаје моделативно у односу на читаву (не само литерарну) стварност, као и појединца у њој: „Ми смо увек унутар/ изван текстуалности, јер текстуалност омогућава да кажемо све о индивидуи, укључујући и то да је индивидуа неизрецива, што је најубедљивија ствар коју можемо да кажемо о индивидуама". ${ }^{45}$

Главни лик Бачићевог романа је млади сликар далтониста, Страхиња. Чудо од детета, које је већ у шестој години маестрално савладало фигуралност и осећај простора, сав свет види у нијансама плаве и жуте, не распознајући притом зелени и црвени део спектра, и уједно се трудећи да тај свој недостатак надомести учењем. Своју различитост тешко му је било, већ од раног детињства, да објасни друговима:

Milana je to još više zbunilo jer kako je moguće da neko ne razlikuje samo dve boje, $i$ zašto ne pije lekove kada je bolestan? Strahinja mu je potom objasnio da za tu bolest ne postoji lek, da jednostavno mora da nauči koji su predmeti crveni, a koji zeleni i tako mora da slika. Međutim, Milan je $i$ dalje verovao da mora postojati neka vakcina kojom se to može izlečiti. ${ }^{46}$

Ово неразумевање исходиште је настојања да се свака различитост излечи, вакцином, или другим репресивним мерама, нпр. ликовнокритичком нормом (која ће одбацити све што није у складу с поетичким каноном који је она кодификовала - па тако и читав Страхињин опус) или било којим другим мерама које имају за циљ да се индивидуа саобрази стандардима нормативног идентитета.

Међутим, у привредном, економском, образовном, етичком, као и сваколиком другом погледу грађанским ратовима и инфлацијама девастираном друштву (каквим, се у роману, приказује АП Војводина - од лета 1990. до маја месеца 2012. - наративном времену романа) у коме мало шта још

44 Volk, M. Rekvijem Ivana Bačića, predgovor u: Bačić, I. (2015) Krvavo zeleno, Beograd: Nova poetika - Argus books \& Magazines, str. 5.

45 Луси, Н. нав. дело, стр. 180.

46 Вас̌ić, І. нав. дело, стр. 32. 
функционише, наметање било какве норме постаје израз лицемерја заједнице у односу на све оне (младе) људе којима она није пружила пр(а)ву шансу. Главни лик, зато, постаје симболичка фигура - парадигма свих оних одбачених талентованих младих људи. Приликом организације постхумне изложбе његових радова, у Кули (његовом родном граду), Наташа објашњава реторику назива изложбе - Крваво зелено - реквијем једној младости (уједно и наслова романа):

„Strahinja je, kao što vam je već možda poznato, bio daltonista. Nije razlikovao crvenu i zelenu boju," govorila je Nataša. „Zbog tog hendikepa nije primljen u srednju grafičku školu, kao ni na umetničku akademiju. Strahinja je umro mlad, otud zeleno. Međutim, zeleno ne predstavlja samo njega, već čitavu jednu generaciju mladih, koji su stradali u ovom suludom, naopakom vremenu. Strahinjin život bio je težak, strašan, mukotrpan, jednom rečju - krvav; otuda krvavo u nazivu. Ipak, verujem da će svako naći već neku svoju simboliku u nazivu." ${ }^{47}$

Ово редуковање симболике наслова припада перспективи главног женског лика, Наташи, Страхињиној девојци, и, по свему судећи, будућој мајци њиховог детета и не би је требало изједначавати нити с intentio lectoris ни с intentio auctoris. ${ }^{48}$ Овај лик, сведен на стрпљиву и толерантну Страхињину пратиљу, младу музичарку и једину која има вере у Страхињин таленат није добио могућност пуне индивидуализације, односно само је уобличен на нивоу персонализације и у извесној мери схематизован.

За разлику од ње, Страхиња добија пуну индивидуализациjу, остварену, пре свега, посредством своје различитости, неуклапања, а потом и противречности карактера који из тога проистиче (он дубоко у себи жели да буде прихваћен, а уједно постепено сам одбацује све себи блиске људе, не марећи за њихове жеље и потребе). Монструозна освета над владиком, кога (у наративном току који прераста у трагање за непознатим починиоцем сексуалног злостављања над дванаестогодишњим Страхињом) на крају, на основу тетоваже, препознаје као свог силоватеља, изискује приступ који би измирио психоаналитичке премисе, склоне да у овом чину виде избој Страхињине праве природе, где се он, коначно, поистовећује с агресором, допустивши да зло које припада опресивном свету, на крају, постане део његове сопствене природе и могућих социокултурних читања, склоних да у

47 Исто, стр. 215.

48 Eko, В. нав. дело. 
Страхињи виде жртву друштва. Стога би и овом сегменту текста требало приступити деконструктивистички и бити изнад ових (привидно) противречних читања, деридијанским укидањем било позитивног, било негативног квалификовања овог чина, чије би право значење требало тражити тек у релацији према другим чиновима.

Страхиња укида зло из свог непосредног окружења тиме што убија владику, а потом (знајући да је алергичан на рибу), симболичком причести рибом, на Велики петак, у затвору, извршава самоубиство, симболички се искупљујући овим чином и остављајући свету своје најбоље - слике (злоупотребљене у материјалистичкој култури као и он сам као средство за прикривање транспорта кокаина). Постхумна изложба Страхињиних слика представља, уједно, симболички чин (научно-технолошког) обесвећења тајне његове уметности:

„Slideshow, na ovom monitoru, prikazuje sve izložene slike provučene kroz Chromatic Visual Simulator, koji je razvio japanski naučnik, Kazunori Asada. Simulator je dostupan za android i iphone uređaje, možete ga besplatno uzeti i pogledati slike direktno vašom kamerom. Naime, za vas koji niste upoznati, Strahinja je bio daltonista. Preciznije, njegov vid patio je od deuteranopia oblika daltonizma, i onemogućavao mu je da vidi crvenu i zelenu boju [...] To se, naravno nije odrazilo na njegovo slikanje, ali jeste - na njegovo školovanje. Zbog svog hendikepa, Strahinja nije primljen na likovnu akademiju i nikad nije postao akademski slikar, iako svojim delima zaslužuje mesto među njima. Ipak, simulator koji je razvio gospodin Asada, omogućava nama, koji imamo normalan vid, da svet pogledamo očima onih koji vide drugačije. Stoga, da bismo u potpunosti razumeli Strahinjine slike, moramo ih pogledati njegovim očima." $" 49$

Но, читалац не мора пристати на то да прихвати virtual tour који је понуђен посетиоцима ове изложбе. Међутим, он не може а да на препозна референце из реалности - распад СФРЈ, злочине на Косову, преживљавање од шверца горива и цигарета, све до тракторских блокада по Војводини. Излазећи из приче бившег полицајца, посветом која, привидно, не припада роману, аутор се, у својеврсној пансемиози, поиграва стратегијама означитељских пракси, тако да се сам роман, на крају, уобличава у интерпретацију нашег друштва и времена, тачније - његову оштру критику. ${ }^{50}$

49 Исто, стр. 217.

50 Посвета завршава реченицом: „U znak sećanja na svog ujaka, Zoltana Prella, da se njegovo ime nikada ne zaboravi, a ujedno u znak svih čiji su životi 
Различитих уметничких израза и домета, поетичких парадигми на којима су уобличени, ови романи, осим очигледне тематске сличности (која, само на површно читање, изгледа као оријентација ка бизарном), имају још једну, свима иманентну особину. Сва три романа приказану болест користе као полазиште за разматрање Различитости у контексту премиса које се за њу везују у грађанском друштву с краja XX, односно почетка XXI века, сходно којима „други” и другачији постају не више заробљеници те различитости, већ културе саме и улога које им она додељује, тиме их симболички подјармљујући. ${ }^{51}$ На тај начин, разматрани романи постају критика културе саме, односно њених конвенција о „другима” и другачијима.

\section{ЛИТЕРАТУРА:}

Bužinjska, A. i Markovski, M. P. (2009) Književne teorije XX veka, Beograd: Službeni glasnik.

Volk, M. Rekvijem Ivana Bačića, predgovor u: Bačić, I. (2015) Krvavo zeleno, Beograd: Nova poetika - Argus books \& Magazines.

Dunđerin, A. Evropski nadrealizam Veselina Markovića, 7. 7. 2011, 15. 10. 2015. http://www.pecat.co.rs/2011/07/evropski-nadrealizamveselina-markovica/

Đorđević, J. (2009) Postkultura, Beograd: Clio.

Eko, U. (2001) Granice tumačenja, Beograd: Paideia, 2001.

Kaler, Dž. (2009) Teorija književnosti: sasvim kratak uvod, Beograd: Službeni glasnik.

Лешић, 3. (2010) Теорија кьижевности - 2. изд., Београд: Службени гласник.

Луси, Н. Реторичко читање, у: Къижевна реторика, приредио Радовић, М. (2008), Београд: Службени гласник.

Marković, V. (2011) Mi različiti-2. izd. Beograd: Stubovi kulture.

Татаренко, А. (2013) Поетика форме у прози српског постмодернизма, Београд: Службени гласник.

upropašteni u prašumskim uslovima ovog podneblja, napisao sam roman $\mathrm{Kr}$ vavo zeleno."; Исто, стр. 221.

51 Другим речима, „odnos prema 'drugom' uvek je ambivalentan: s jedne strane, on izaziva strah i anksioznost, često mržnju, s pratećim stavovima obezvređivanja i isključivanja, zasnovanim na logici radikalne polarizacije. S druge strane, drugi izvor mogućnosti je potencijal društvenog obogaćivanja i obnove, izazov i poziv za širenje granica i sadržaja vlastite realnosti. U tom smislu, 'drugi' može postati aktivan princip transformacije, aktivirati imaginaciju, afekte, predstave kojima se usložnjava, on može da cepa stari i ponovo slaže novi identitet”; Đorđević, J. (2009) Postkultura, Beograd: Clio, str. 354-355. 
Ћирјанић, Г. (2007) Пољубаи - 3. изд., Београд: Народна књига Алфа.

Штанцл, Ф. (1987) Типичне форме романа, Нови Сад : Књижевна заједница Новог Сада.

Dragoljub Ž. Perić

University in Novi Sad, Faculty of Paedagogy in Sombor Department for Language and Literature, Sombor

\title{
NARRATIVE STRATEGIES IN PORTRAYING CHARACTERS WITH DISORDERS IN THE SERBIAN NOVEL AT THE BEGINNING OF THE 21ST CENTURY
}

\begin{abstract}
This paper considers different narrative strategies and manners of modelling characters with various disorders as the "other" in the Serbian novel at the beginning of 21 st century, in the context of the post-postmodernist poetics and the post-structural (Foucauldiandeconstructionist) interpretative paradigm. Even though at first glance it seems that such interest of novelists provides proof for a crisis of narration exhausted in an interest in the bizarre, the case is quite the opposite. The results show that the differences of this kind in the novels in question are depicted not as stigmatization, but as a struggle for the right of having one's own identity, regardless of the fact it does not meet the normative identity standards.
\end{abstract}

Key words: post-postmodernism, novel, illness, identity, otherness, social role

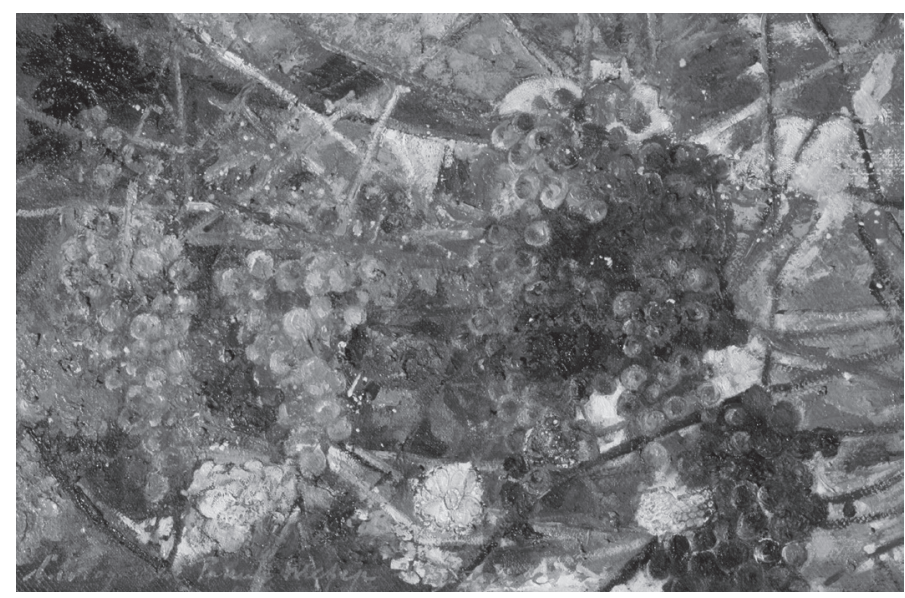

Слободанка Ракић Шефер,

Градска лоза, уље на платну, 2015. 